\title{
UPAYA MENINGKATKAN MOTIVASI BELAJAR MELALUI KONSELING KELOMPOK PADA SISWA KELAS IX A MTs NEGERI 1 KENDAL SEMESTER GANJIL TAHUN PELAJARAN 2019 / 2020
}

\author{
SLAMET AGUS BUDIYONO \\ Guru MTs. Negeri 1 Kendal, Jawa Tengah \\ Email: budiono2121@gmail.com
}

\begin{abstract}
ABSTRAK
Pendekatan pembelajaran dengan Metode Problem-Based Learning merupakan konsep belajar yang membantu guru mengaitkan antara materi yang diajarkan dengan situasi dunia nyata siswa dan mendorong siswa membuat hubungan antara pengetahuan yang dimilikinya dengan penerapannya dalam kehidupan mereka sebagai anggota keluarga dan masyarakat. Dengan konsep itu, hasil pembelajaran diharapkan lebih bermakna bagi siswa. Proses pembelajaran berlangsung alamiah dalam bentuk kegiatan siswa bekerja dan mengalami, bukan mentransfer pengetahuan dari guru ke siswa. Strategi pembelajaran lebih dipentingkan daripada hasil. Tujuan dari penelitian tindakan kelas (PTK) ini adalah untuk mengetahui sejauh mana peningkatkan Hasil belajar siswa pelajaran IPS dengan menerapkan Metode ProblemBased Learning . Dalam penelitian tindakan kelas (PTK) ini dilakukan dalam 2 siklus, dari hasil tindakan yang dilakukan terbukti dapat meningkatkan Hasil belajar siswa dengan mencapai standar ideal. Dari 61,94\% pada siklus I, dapat meningkat pada siklus VI menjadi $100 \%$. Hasil penelitian tindakan ini menunjukkan bahwa penerapan pembelajaran dengan Metode Problem-Based Learning dapat meningkatkan ketuntasan belajar siswa pada pelajaran IPS dengan ketuntasan mencapai $100 \%$.
\end{abstract}

Kata Kunci: Motivasi belajar, konseling kelompok

\section{PENDAHULUAN}

Penyelenggaraan pendidikan yang bermutu, efektif, ideal dan berdaya guna adalah yang mengintegrasikan tiga bidang kegiatan utamanya secara sinergi, yaitu bidang administrasi dan supervisi, bidang pengajaran, serta bidang bimbingan dan konseling. Pendidikan yang hanya melaksanakan bidang administrasi dan pengajaran dengan mengabaikan bidang bimbingan dan konseling, hanya akan menghasilkan peserta didik yang pintar dan terampil dalam aspek akademik, tetapi kurang memiliki kemampuan atau kematangan dalam aspek kepribadian.

Dalam perkembangan ilmu dan teknologi serta perkembangan sosial budaya yang pesat dewasa ini memberikan tantangan tersendiri bagi guru dan peserta didik dalam meningkatkan prestasi belajar. Setiap peserta didik senantiasa ditantang untuk terus meningkatkan kegiatan belajarnya melalui berbagai sumber dan media seperti internet, televisi, perangkat audiovisual, selain belajar langsung dari guru. Sedangkan guru senantiasa ditantang untuk bisa mendorong, membimbing, dan memberi fasilitas belajar bagi peserta didik. Melalui peranannya sebagai pengajar guru diharapkan mampu memberikan motivasi pada anak untuk belajar dalam berbagai 
kesempatan, guru hendaknya dapat mengembangkan cara dan kebiasaan belajar yang baik, sehingga peserta didik memiliki motivasi yang kuat untuk belajar dan pada akhirnya bisa mencapai hasil belajar yang optimal.

Namun kondisi nyata di lapangan tidaklah menunjukan kondisi ideal yang diharapkan. Berdasarkan hasil pengamatan ditemukan banyak siswa yang motivasi belajarnya rendah. Hal ini bisa dilihat dari sikap dan perilaku siswa yang malas belajar, sering tidak mengerjakan tugas/PR yang diberikan oleh guru pengampu mata pelajaran, tidak memperhatikan pelajaran, tidak serius dan tidak konsentrasi dalam proses pembelajaran, suka ramai di kelas, sering membolos pelajaran tertentu, dan sering membolos les, sehingga pada akhirnya berdampak pada nilai ulangan harian yang rendah atau prestasinya kurang.

Berkaitan dengan sejumlah siswa yang terindikasi prestasi belajarnya rendah yang terjadi pada siswa, perlu diberikan layanan yang bisa mengakomodasi kepentingan sejumlah siswa tersebut secara bersama-sama seperti layanan konseling kelompok. Konseling kelompok adalah suatu upaya bantuan kepada peserta didik dalam suasana kelompok yang bersifat pencegahan dan penyembuhan, diarahkan kepada pemberian kemudahan dalam rangka perkembangan dan pertumbuhannya (Wibowo, 2005).

Motivasi belajar menurut McClelland, Atkinson, Clark \& Lowell (1958) dan Schunk, Pintrich \& Meece (2008) diartikan sebagai usaha yang dapat menyebabkan siswa tergerak melakukan sesuatu yang baru karena ingin mencapai tujuan yang diinginkan agar terjadi perubahan pada dirinya. Dari uraian tersebut dapat disimpulkan bahwa motivasi belajar adalah keseluruhan daya penggerak baik dari dalam diri maupun dari luar siswa dengan menciptakan serangkaian usaha untuk menyediakan kondisi-kondisi tertentu yang menjamin kelangsungan dan memberikan arah pada kegiatan belajar, sehingga tujuan yang dikehendaki oleh subjek belajar itu dapat tercapai.

Rumiani (2006) berpendapat bahwa dalam hal motivasi belajar menurut asalnya dapat di golongkan menjadi 2 macam yaitu: (1) Motivasi intrinsik, yaitu motivasi yang berasal dari dalam diri sendiri. Motivasi ini dapat muncul karena: Merasakan pentingnya belajar, Merasakan dan mengetahui kemajuannya sendiri dari hasil belajar, dan Mempunyai keinginan untuk meraih cita-cita dengan cara belajar. (2) Motivasi ekstrinsik, yaitu motivasi yang berasal dari luar diri sendiri. Hal yang bisa menimbulkan motivasi ekstrinsik adalah: Ganjaran (award), Hukuman (Punishment), dan Persaingan (competition).

Dalam proses pembelajaran ada siswa yang memiliki motivasi tinggi dan motivasi itu berkembang dari dalam diri mereka sendiri. Sebaliknya tidak sedikit siswa yang motivasi belajarnya rendah sehingga harus ada upaya bimbingan terhadap siswa dari guru BK untuk mengembangkannya. Dari beberapa siswa yang memiliki motivasi rendah maka peneliti akan meneliti berkaitan dengan siswa yang sering terlambat di kelas, tidak mengerjakan PR atau tugas yang diberikan gurunya, tidak konsentrasi atau ramai setiap mengikuti pelajaran, malas saat belajar, dan siswa yang sering mendapat nilai rendah dalam hasil ulangan sekolah.

Adapun konseling kelompok adalah layanan yang membantu peserta didik dalam pembahasan dan pengentasan masalah pribadi melalui dinamika kelompok 
(Depdiknas, 2002: 6). Jadi konseling kelompok merupakan upaya untuk membantu peserta didik agar dapat menjalani perkembangannya dengan lancar, baik yang bersifat preventif maupun bersifat perbaikan/pengentasan terhadap masalah-masalah pribadi yang di alami oleh masing-masing anggota kelompok (Wibowo, 2005). Kegiatan konselor menurut Gunawan, Wibowo, Purwanto \& Sunawan (2019) dalam melaksanakan konseling kelompok pada umumnya melalui empat tahap, yaitu: (1) Tahap Pembentukan yang terdiri dari: Menjelaskan tentang pengertian dam tujuan kegiatan kosenling kelompok, Menumbuhkan rasa saling mengenal antar anggota , Menumbuhkan sikap saling mempercayai dan menerima, dan Melakukan permainan ringan agar terjadi suasana keakraban dan gembira. (2) Tahap Peralihan yang terdiri dari: Konselor menjelaskan kegiatan yang akan ditempuh pada tahap berikutnya, Menawarkan atau mengamati apakah anggota sudah siap menjalani kegiatan pada tahap selanjutnya, dan Meningkatkan keikutsertaan anggota. (3) Tahap Kegiatan yang meliputi: Masing-masing konseli secara bebas mengemukakan masalah atau topik bahasan, Menetapkan topik yang akan dibahas dulu, dan Konseli membahas masing-masing topik secara mendalam dan tuntas, disamping itu perlu diadakan kegiatan selingan. (4) Pengakhiranyang meliputi: Penjelasan konselor bahwa kegiatan akan diakhiri, Konselor dan konseli mengemukakan kesan dan hasil-hasil kegiatan, Membahas kegiatan lanjutan, dan Mengemukakan pesan dan harapan.

\section{METODE PENELITIAN}

Jenis penelitian ini adalah penelitian tindakan kelas (PTK). Penelitian tindakan kelas (PTK) merupakan suatu proses investigasi terkendali yang berdaur ulang dan bersifat reflektif mandiri yang dilakukan oleh guru yang memiliki tujuan untuk melakukan perbaikan-perbaikan terhadap sistem, cara kerja, proses, isi, kompetensi, atau situasi pembelajaran. Penelitian tindakan kelas (PTK) ini dilaksanakan pada semester gajil tahun pelajaran 2019/2020. Penelitian tindakan kelas ini dilaksanakan di MTs. Negeri 1 Kendal. Penelitian ini dilaksanakan dengan menggunakan dua siklus, dengan setiap siklusnya dilaksanakan proses konseling kelompok kemudian dilaksanakan evaluasi. Penelitian ini dilaksanakan selama kurang lebih tiga bulan. Subyek penelitian adalah siswa kelas 9-A MTs. Negeri 1 Kendal yang berjumlah 30 orang siswa.

\section{HASIL DAN PEMBAHASAN}

Sebelum dilaksananakan tindakan bimbingan dan konseling, peneliti melaksanakan kegiatan wawancara dan observasi terhadap 9 siswa yang mempunyai motivasi belajarnya cukup rendah, baik melalui wali kelas maupun siswa tersebut. Dari hasil wawancara dengan guru mata pelajaran yang merangkap wali kelas terhadap sembilan siswa tersebut diperoleh data sebagai berikut: 
Tabel 1. Hasil wawancara Permasalahan siswa

\begin{tabular}{clcc}
\hline No & \multicolumn{1}{c}{ Permasalahan } & Jumlah & Keterangan \\
\hline 1 & Sering terlambat & 6 & \\
2 & $\begin{array}{l}\text { Sering membolos atau tidak berangkat tanpa } \\
\text { keterangan }\end{array}$ & 4 \\
3 & Sering tidak mengerjakan tugas guru & 7 \\
4 & Sikap malas atau enggan pada saat mengikuti pelajaran & 4 \\
5 & Nilai ulangan harian selalu rendah & 9 \\
& $\quad$ Jumlah & 30 \\
\hline
\end{tabular}

Berdasarkan tabel di atas menunjukkan bahwa kondisi 9 siswa sebelum dilaksanakan layanan konseling kelompok diperoleh hasil 6 siswa sering terlambat (67\%), 4 siswa sering membos (44\%), 7 siswa sering tidak mengerjakan tugas guru (78\%), 4 siswa menunjukkan sikap malas atau enggan pada saat mengikuti pelajaran (44\%) dan dari 9 siswa semuanya mempunyai nilai ulangan harian selalu rendah (100\%). Dari hasil tersebut kami memberikan layanan konseling kelompok untuk meningkatkan motivasi belajar siswa melalui dua siklus, dan masing-masing siklus diberikan 2 kegiatan layanan konseling. Setiap tahapan kegiatan layanan konseling kelompok diupayakan tindakan pembaharuan atau penyempurnaan pada setiap tahapan untuk diterapkan pada siklus berikutnya, yaitu:

1. Tahap Pembentukan

Peran konselor dalam tahap ini adalah menampilkan penghormatan kepada anggota konseling kelompok. Pengertian tekstual asas-asas penyelenggaraan konseling kelompok boleh jadi berbeda dengan kondisi nyata pada diri di antara anggota. Misalnya tentang asas keterbukaan, sementara di antara anggota kelompok ada yang memiliki sifat tertutup. Agar anggota yang memiliki sifat tertutup tersebut tidak merasa "terancam" maka penjelasan asas keterbukaan harus dibalut dengan asas kerahasiaan. Dalam upaya menghormati anggota kelompok konselor perlu melakukan tindakan empati dalam tindakan nyata, tidak sekedar mengetahui definisi empati. Empati dapat dilakukan dengan pernyataanpernyataan yang mengandung unsur baru, seperti : "Kehadiran anda di sini pasti ada sesuatu yang penting untuk dibicarakan" sebagai pengganti dan pembaharuan dari pernyataan "Ada yang bisa saya bantu?" sebagaimana dikatakan oleh konselor pada umumnya. Pernyataan tersebut merupakan ekspresi yang bisa ditangkap oleh anggota konseling kelompok bahwa konselor menaruh perhatian, mempunyai kepedulian dan memiliki anggapan bahwa masalah yang dirasakan merupakan sesuatu yang harus diupayakan penyeselesaiannya, tidak sekedar ingin mengetahui apa yang dialami orang lain.

2. Tahap Peralihan

Ketergesa-gesaan dalam memberikan penjelasan tentang tahapan kegiatan konseling kelompok hanya akan menghasilkan kebingungan anggota. Untuk 
itulah ketergesa-gesaan perlu diganti dengan kesabaran. Mengingat tahap peralihan merupakan suatu tahapan untuk memasuki tahapan inti, maka penting bagi anggota konseling kelompok untuk memiliki kesiapan dalam kegiatan inti tersebut. Kepada seluruh anggota perlu mendapat kesempatan, tidak hanya pada mereka yang mau/berani berbicara. Anggota kelompok dikatakan siap manakala mereka telah mengetahui peran dan tanggung jawabnya sebagai bagian dari kelompok.

3. Tahap Kegiatan

Masalah yang diangkat dalam aktifitas kelompok diserahkan kepada anggota kelompok, dan posisi konselor cukup sebagai fasilitator yang secara aktif mengikuti arah pembicaraan anggota kelompok, dan apabila dipandang perlu bisa terlibat di dalamnya. Sebagai pengatur dan pemimpin kegiatan konseling kelompok konselor perlu menciptakan komunikasi multi arah. Kegiatan selingan diupayakan dapat memberikan sentuhan baru yang menjadikan suasana menjadi lebih segar, jadi tidak sekedar kegiatan "istirahat".

4. Tahap Pengakhiran

Pada tahap pengakhiran kehangatan tetap dijaga. Perlu diupayakan juga anggota konseling kelompok memiliki keinginan yang kuat untuk kembali mengikuti kegiatan layanan konseling kelompok pada sesi berikutnya.

Kemudian setelah kami melaksanakan kegiatan layanan konseling kelompok baik pada siklus I maupun siklus II, kami melakukan pengamatan dan wawancara kembali pada wali kelas untuk memperoleh hasil dari pengaruh layanan konseling kelompok terhadap meningkatnya motivasi belajar siswa. Dari hasil wawancara tersebut diperoleh data sebagai berikut:

Tabel 2. hasil dari pengaruh layanan konseling kelompok terhadap meningkatnya motivasi belajar siswa

\begin{tabular}{|c|c|c|c|c|c|}
\hline \multirow[t]{2}{*}{ No } & \multirow[t]{2}{*}{ Permasalahan } & \multicolumn{3}{|c|}{ Kondisi Siswa } & \multirow[t]{2}{*}{ Keterangan } \\
\hline & & $\begin{array}{c}\text { Kondisi } \\
\text { awal }\end{array}$ & Siklus I & Siklus II & \\
\hline 1 & Sering terlambat & 6 & 2 & - & \\
\hline 2 & $\begin{array}{l}\text { Sering membolos atau tidak berangkat } \\
\text { tanpa keterangan }\end{array}$ & 4 & 1 & - & \\
\hline 3 & Sering tidak mengerjakan tugas guru & 7 & 2 & - & \\
\hline 4 & $\begin{array}{l}\text { Sikap malas atau enggan pada saat } \\
\text { mengikuti pelajaran }\end{array}$ & 4 & 3 & - & \\
\hline \multirow[t]{2}{*}{5} & Nilai ulangan harian selalu rendah & 9 & 7 & 3 & \\
\hline & Jumlah & 30 & 15 & 3 & \\
\hline
\end{tabular}


Berdasarkan tabel di atas menunjukkan bahwa kondisi 9 siswa sebelum dilaksanakan layanan konseling kelompok diperoleh hasil 30 masalah tentang rendahnya motivasi belajar. Untuk meningkatkan motivasi belajar siswa maka peneliti mengadakan konseling kelompok melalui dua siklus dengan masing-masing siklus diberi dua kali layanan konseling kelompok.

Pada siklus pertama diperoleh hasil bahwa konseling kelompok tersebut dapat menurunkan jumlah siswa yang motivasi belajarnya rendah dari 30 item menjadi 15 item atau menurun 50\%. Kemudian pada siklus kedua setelah peneliti mengadakan dua kali layanan konseling kelompok maka diperoleh data bahwa siswa sudah tidak ada yang terlambat, tidak ada siswa membolos, siswa sudah mau mengerjakan tugas guru, siswa sudah menunjukkan sikap senang saat mengikuti pelajaran serta nilai ulangan harian yang diperoleh meningkat mencapai batas KKM kecuali tiga siswa yang masih memperoleh nilai ulangan harian rendah.

Dari hasil pengamatan, penilaian segera dan penilaian jangka pendek melalui hasil ulangan harian dapat dilihat bahwa siswa yang berjumlah 9 anak tersebut sudah bisa menghilangkan perilaku mal adaptif dalam belajar dan mengganti dengan perilaku yang lebih adaptif, sehingga dari hasil penelitian ini dapat di simpulkan bahwa konseling kelompok dapat meningkatkan motivasi belajar siswa.

\section{KESIMPULAN}

1. Hasil pengamatan pra siklus diketahui bahwa ada 9 siswa yang terindikasi memiliki motivasi belajar rendah. Berdasarkan pengamatan dan hasil wawancara dengan guru mata pelajaran menunjukkan bahwa siswa tersebut memang indikasi motivasi belajarnya rendah. Hal ini bisa dilihat dari sikap dan perilaku siswa yang malas belajar, sering tidak mengerjakan tugas/PR yang diberikan oleh guru pengampu mata pelajaran, tidak memperhatikan pelajaran, tidak serius dan tidak konsentrasi dalam proses pembelajaran, suka ramai di kelas, sering membolos pelajaran tertentu, sering membolos, sehingga pada akhirnya berdampak pada nilai ulangan harian yang rendah atau prestasinya kurang.

2. Konseling kelompok efektif digunakan dalam meningkatkan motivasi belajar siswa di sekolah. Hal ini dibuktikan dengan hasil pengamatan setelah peneliti mengadakan konseling kelompok pada siklus I motivasi belajar siswa meningkat $50 \%$ dari pra siklus dan pada siklus II motivasi belajar siswa meningkat $80 \%$ dari siklus I atau secara keseluruhan meningkat $90 \%$ dari sebelum diberikan layanan konseling kelompok.

3. Setelah mengikuti kegiatan layanan konseling kelompok ini, siswa mengalami perubahan perilaku belajar yang positif seperti mau mengerjakan PR, tidak terlambat, tidak alpha ataupun membolos, mengikuti les di sekolah, mengikuti bimbingan belajar. Sehingga dapat disimpulkan bahwa layanan konseling kelompok bisa meningkatkan motivasi belajar siswa kelas 9-A di MTs Negeri 1 Kendal. 
DAFTAR PUSTAKA

Depdiknas. 2006. Undang-Undang No. 20 Tahun 2003 tentang Sistem Pendidikan Nasional. Jakarta: Depdiknas.

Gunawan, I.M.S., Mungin, E.W., Purwanto, E., \& Sunawan, S. (2019). Group counseling of values clarification to increase middle school students' empathy. Psicologia Educativa, 25: 169-174. Doi: https://doi.org/10.5093/psed2019a5

McClelland, D. C., Atkinson, J. W., Clark, R. A., \& Lowell, E. L. (1958). A scoring manual for the achievement motive. In J. W. Atkinson (Ed.), Motives in fantasy, action, and society (pp. 179-204). Princeton, NJ: D. Van Nostrand Company, Inc.

Rumiani. 2006. Prokratinasi Akademik Ditinjau dari Motivasi Berprestasi dan Stres Mahasiswa. Jurnal Psikologi Universitas Diponegoro, (Online), 3 (2): 37-48, (http://www.undip.ac.id) di akses 15 Agustus 2019.

Schunk, D.H; Pintrich, P.R. \& Meece, J.L. 2008. Motivation in Educational: Theory, Research amd Application ( $3^{\text {rd }}$ Ed). New Jersey: Pearson Education, Inc.

Suharsimi, A. 2014. Prosedur Penelitian Suatu Pendekatan Praktik. Jakarta: Rineka Cipta.

Wibowo, M.E. (2005). Konseling kelompok perkembangan. Semarang: UPT UNNES Press. 